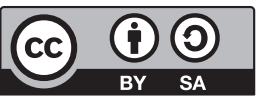

DOI 10.31261/IJREL.2019.5.2.01

\title{
Dmitry Guzhelya
}

Russia (ORCID: 0000-0002-5031-8231)

\section{Victoria Kurilenko}

Russia (ORCID: 0000-0003-3638-9954)

\section{Yulia Biryukova}

Russia (ORCID: 0000-0002-5977-4081)

\section{Distance Technologies in Teaching Professional Foreign Languages for Medical Purposes}

\begin{abstract}
The article presents the analysis of distant technologies that are utilised by the world methodological society: a set of distance technologies (desktop videoconferencing, e-mail, voicemail, online chat, web-based resources, e-learning platforms), synchronous/asynchronous technologies, m-learning/e-learning technologies. These technologies were analysed from scientific positions concerning their typology, essential characteristics, and linguistic and methodological potential.

The authors of the article also provide distance technologies that can be used when teaching Russian language as foreign for medical purposes: synchronous technologies, professional websites, e-learning platforms, e-mails, mobile applications.

The verification of distant technologies' usage is conducted experimentally. The obtained results show that distance learning is useful and should be used in teaching foreign languages for other levels and professional purposes.

Not only does the success of distance educational courses depend on the distance technologies that are provided by a teacher, but also we should rely on the consistent and integrated efforts of students, faculty, facilitators, support staff, and administrators.
\end{abstract}

K e y w o r d s: distance learning, teaching professional foreign languages, distance technologies, medical Russian 
Nowadays, the significant transformations are taking place in the higher education systems of many countries. It is connected with the digital technologies' rapid development. Many universities offer both the traditional learning mixed with the elements of distance learning, or just the distance learning or e-learning. The students have got an option of studying at the campus or at home, preparing for the classes and doing tests online.

In scientific and methodological literature, one can find a variety of definitions of distance learning or e-learning. Many scientists find out some characteristics that are different from the traditional learning. First of all, it is the separation of the teacher and the learner, and special relationship between each other, anticipation of the two-way communication, saving time for the learner and the institute (Unwin \& Mc Aleese, 1988; Liu \& Ginther, 1999; Schlosser et al., 2002, 2009; Arafeh, 2004; Chongwony, 2008).

Informatisation and digitalisation can be recognised as the leading trends of the modern stage of development of the world educational systems. The introduction of distant digital technologies can significantly optimise the process of educational training and gives the opportunities for the use of innovative resources that provide high-quality, intensive, personality-oriented learning interaction. Teachers of foreign languages (including teaching foreign languages for professional purposes) are actively involved into the development of technologies of distance language education: in recent years, a large number of effective electronic language educational tools of various genres and formats have been created, allowing to solve both complex and aspect problems of formation and development of professional and communicative competence of foreign specialists. For cultural and language training of foreign medical specialists, specialised sites, electronic textbooks, and manuals are developed. The teachers of Peoples' Friendship University of Russia are creating a network professionally-oriented module "Test of Russian as a foreign language (levels B1-B2)."

Distance professionally-oriented training in a foreign language is in a great demand for two categories of students. The first category includes foreigners who plan to study in foreign countries. If the foreigner is going to enter the medical university in another country and he or she does not have an opportunity to come and study at the preparatory faculty or local language courses to be able to become a student the following year, the distance education will be the only appropriate way of language learning for future studying.

Another referent group that in most cases would choose the distance learning may be represented by a professional group of post-graduate students (doctors, provisors, etc.) that finished the basic education in foreign medical university but need to improve the skills of professional communication on this or that purpose.

In recent years, this direction has been significantly updated in Russia. Currently, medical tourism is extremely popular among Russian patients; its geography includes both European and Asian destinations. In addition, the active 
development of telecommunication medical technologies in Russian Federation has led to the emergence of dozens of foreign medical organisations offering online consulting, international medical web-co-meetings, network conferences, etc.

As a rule, the practitioners have no time to study in extensive mode. Or the reason to study in the individual educational route may be that the foreign language is learnt outside the language environment. It happens in case the person studies in a foreign country for some years and then he or she returns back home, and it is necessary for him or her to continue improving the skills of Russian grammar and learn new terms, for example.

While teaching professional language for medical purposes, distance learning undoubtedly plays an important role. In order for this training to be effective and efficient, when creating distance learning courses, teachers need to use a variety of distance technologies that allow interactive online communication of students and teachers in the learning process. They give the learner autonomy in the process of studying. Let us take a closer look at distance technologies and electronic resources offered by the modern methodological community. We will analyse scientific positions concerning their typology, essential characteristics, and linguistic and methodological potential.

\section{Literature Review}

The researchers present the following classifications of distant technologies that are often used in the process of learning: desktop videoconferencing, e-mail, voicemail, online chat, web-based resources, e-learning platforms (SmyrnovaTrybulska, 2016; Towhidi, 2010; Prigozhina \& Trostina, 2016; Brenton, 2009; "Distance Education Models and Best Practices...," 2011).

Desktop videoconferencing allows for "real time" visual contact between students and the instructor or among students at different sites. Sometimes it is necessary to have an eye contact with students for them to see something from the teacher. Videoconferencing may include behaviour modeling, demonstration, and instruction of abstract concepts. It is possible to arrange videoconferencing through Skype.

E-mail or electronic mail may be used to exchange messages and distribute files as attachment or other information between students and teachers through a computer network to a computer address.

Online chat, or instant messaging, is usually shared between a teacher and a student or a group of students in virtual chat room. The teacher can establish virtual class hours to answer the students' questions or engage subjects in an online course discussion. 
Voicemail is often used in distant learning. The teachers and students can leave messages regardless of the time. This technology can substitute for e-mail and reduce the time for typing the message if it is not necessary to check the written form of it. We can send the messages with the help of WhatsApp or Viber or any other application that gives us an opportunity to exchange instant messages.

Web-based resources are very popular among the teachers and their students. Students may find a lot of useful information at websites, weblogs, and podcasts, and in such a way improve learning outcomes. With the help of the web technologies teachers can make up a classroom website that covers, for example, the timetable, additional tasks and exercises, links to access the online library, dictionaries, and so on.

E-learning platforms present the virtual learning platform or learning management systems. It is an application that is menu-based or has got a pointand-click interface for making up a course without the help of an IT specialist. Any teacher without technical education may construct it. The platform usually includes special tools to make up the tasks for students (tests, quizzes, exercises), messaging tool, e-portfolio tool for students and teachers. It gives participants an opportunity to upload and download different files. These platforms may be either branded by the university or constructed with the help of free-of-charge environment, for example Moodle environment that has got the similar set of tools.

Moreover, it is necessary to add that IT specialists make up special applications for mobile versions for distant education because nowadays students are more driven towards using a mobile phone for every purpose, including education. It makes the learning process easier.

The analysis shows that all the abovementioned technologies may be mediated by virtual environment that can be used by a participant via either desktop computers or mobile devices. In this connection the researchers find e-learning and m-learning. The latter is an extension of e-learning which is performed using mobile devices such as tablet PCs, mobile phones, laptops on the one hand ( $\mathrm{Sad} \&$ Goktas, 2013; Motiwalla, 2007); on the other hand, m-learning has got its certain characteristics: portability through mobile devices, wireless Internet connection and ubiquity, personalisation, collaboration (Kearney, Schuck, Burden, \& Aubusson, 2012). For higher education, m-learning devices allow learners to disseminate information and finish the course even if they are away from desktop PC and hardwired Internet connections. The usage of mobile devices improves collaboration via real-time or instant interactivity that may lead to better decision-making.

Videoconferencing, e-mails, voicemails, web-based resources, and e-mail platforms may be used at both the desktop PC and the mobile device.

In distant education scientists find the two most common online learning technologies: synchronous and asynchronous ones (Hrastinski, 2008; Er et al., 2009; Simonson, Smaldino, Albright, \& Zvacek, 2012). 
Synchronous technologies include desktop videconferencing, online chats, and telephone conferences that provide the participants the multiple ways of mutual communication, sharing, and the ability to collaborate and ask questions in real time.

The analysis of scientific material shows that synchronous communication provides flexibility and offers students personalised learning opportunities. The students have got the opportunity to convey their thoughts online without judgment or interruption (Er et al., 2009). It is a good experience both for the student and for the teacher.

Asynchronous technologies provide unlimited education that is independent from time and place. The students have got the opportunity to study according to their own schedule. They have got the chance to create, synthesise, and apply the content or skills being taught (Harris, Mishra, \& Koehler, 2009; Simonson et al., 2012). In asynchronous learning the student can contact the educator independently of time and place. E-mail, voicemail, web-based resources, and e-learning platforms give the participants the opportunity to arrange the asynchronous learning that provides education for all categories of people, including the people with limited access to educational facilities because of social, economic, geographic, or other reasons.

While creating a distant course, teachers should take into their consideration the fact that every technology that is used by them should be carefully planned and correspond to the requirements and students' needs.

In teaching foreign languages (Russian as a foreign language), the group of teachers of Russian Language Department of the Institute for Medicine (Peoples' Friendship University (RUDN University)) has developed several distant courses to arrange the education support for students that study Russian language as foreign for medical purposes at different levels. The authors may suggest the following distant technologies.

\section{Distant Technologies in Practice}

To describe the distant technologies for teaching Russian language for medical purposes, it is reasonable to take into consideration the classifications of distant technologies presented above. All of them can be successfully used in the process of education of a future doctor.

Such synchronous technologies as desktop videoconferencing or online chats are often used by students to connect with the teacher by WhatsApp, Viber, or Skype using their mobile devices. As the experience shows, students communicate mostly if they have got some problems in understanding grammar material or if 
they do not know how to pronounce this or that word or expression. Sometimes they leave the voicemail if they cannot find the teacher online.

Asynchronous technologies that let the participants study from any point of the world are the following: special websites, e-learning platforms, e-mails, and mobile applications.

\section{Specialised Websites on Teaching Russian as a Foreign Language}

Specialised websites that contain tasks for studying and various methodological materials may be effective means of teaching professional communication to foreign specialists.

As a rule, specialised educational websites, the purpose of which is the formation and development of professional and communicative competence, contain a variety of educational materials on Russian as a foreign language. Their main function is informative.

However, specialised websites on teaching Russian language as foreign can have varying orientations and structures. Depending on these, one can distinguish the following groups of specialised websites:

- websites - electronic versions of paper textbooks, which can be found on the websites of most universities; for example, on the website of the Moscow Road Institute in the electronic library one can download electronic versions of paper textbooks on Russian language as foreign for future doctors and engineers (http://www.madi.ru/1211-elektronnaya-biblioteka-podgotovitelnogo-fakultetadlya-ino.html);

- websites - multimedia textbooks on Russian language as foreign, which are the means of basic training on Russian language as foreign in a certain professional sphere; this type of site usually involves various forms of combination of fulltime and distance learning. An example is the multimedia interactive complex "Business Russian," developed at the at Peoples' Friendship University of Russia under the guidance of doctor of pedagogical sciences, Professor T. M. Balykhina; the specificity of the textbook is that there are materials not only to train the vocabulary and grammar, or types of speech activity, but there is also a large block of materials on the culture of business communication. The structure of the textbook is modular, so the course is flexible and adaptive: one can choose the skills that students need in a specific learning environment. The textbook is interactive, so one can work in a group both under the guidance of a teacher and independently: there are tips, methodological comments, answers to control tasks, which are given in the test form (http://www.rusist24 .ru/index.php/obuchenie/katalog-uchebnykh-programm/343-russkij-yazyk-v -sfere-biznesa.html);

- websites for testing, assessment of knowledge, which contain test tasks designed to determine and assess the level of professional ownership of the RCT; so, on the website of the Pushkin State Russian Language Institute, one can take a test 
in Russian language for special purposes on the profile "Russian language in the international tourism business" (http://www.pushkin.institute/Certificates /CCT/tests-online.php);

- websites - libraries of electronic visual aids and databases, for instance, on the site "Library.Medica" students studying Russian as a foreign language can get acquainted with various manuals in Russian, which will allow them to get the necessary information in the learning process (http://meduniver.com /Medical/Book/);

- websites - platforms that contain different resources for different learning profiles; one of the examples is the website "Learn Russian," where students and teachers of the Russian language as foreign can find lessons for medical students that receive their education in Russian. It includes sections: biology, pharmacy, various presentations, terms and terminological combinations, additional materials. One can learn Russian in different languages except Russian: English, German, French, Italian, Serbian, Chinese. There is a view mode with accents. The website also contains educational texts with exercises, educational dialogues: "at the doctor's," "at the pharmacy," "how to call the doctor," "at the doctor's. Sore throat," dictionaries and educational dictionaries, including dictionaries in pictures, thematic, lexical, and grammatical ones, etc. (http://rus.lang-study.com/).

Having analysed the different types of specialised websites on teaching Russian as a foreign language which are represented on the Internet, we can conclude that the above classification is quite heterogeneous. At the moment, there is a tendency to create learning platforms that can be large in terms of educational information and include all of the above types of specialised websites for Russian as a foreign language.

At the Russian Language Department of the Institute for Medicine (RUDN University), a specialised website was developed - a platform for medical students studying Russian as a foreign language and teachers that can apply to the training course and develop the particular material independently or with the help of the teacher.

\section{Specialised Website "Let's Speak about Medicine in Russian. Medical Russian"}

The main task of the website "Let's speak about medicine in Russian. Medical Russian" is to give the information and methodological support for both foreign doctors and teachers of Russian as a foreign language.

The site contains materials for foreign students studying medicine, pharmacy, and dentistry. The site has the following structure: each of the five main sections - "Russian language as foreign for students," "Russian language as foreign for residents," "Russian language as foreign for graduate students," "Russian language as foreign for applicants" (the Department trains a certain number of foreign 
students that study medical Russian at B1 level of Russian as foreign language), "Methodical bank" - has several subsections.

Sections addressed to students have a similar structure. There are exercises aimed at the formation of terminological competence of the students ("Learning Russian medical terminology"), at practising grammar skills ("Learning the grammar of the Russian medical discourse"), at the development of skills to create a monological utterance ("Learning to talk about organs and the human body," etc.), at dialogue speech ("Learning to discuss medical problems"), and at skills and abilities of reading ("Reading the texts on medicine").

In the section that is addressed to foreign students, there is an audio support of the main course: students can independently practise pronouncing the main terms of the topic, work on intonation, etc. (audio application includes recorded vocabulary and texts of lessons of textbooks).

Electronic courses of professional and communicative training of foreign medical students, of course, have "paper" text that is developed for all specialties which students study: "Let's talk about medicine in Russian," "Let's talk about pharmacology in Russian," "Let's talk about dentistry in Russian." The content of the textbook follows the logic of change priority areas of communication: teaching science $\rightarrow$ educational skills $\rightarrow$ scientific and professional. In this regard, in the first part of each textbook we train educational and scientific communication (leading text genre-educational and scientific), in the second - educational and professional communication (leading genre-questioning the patient), in the third scientific and professional communication (leading genre-scientific article).

The section "Methodical bank" contains methodological resources that allow teachers of Russian as a foreign language to carry out professional activities most effectively. For example, the teacher can find guidelines how to teach foreign students strategies of questioning patients, how to work with grammatical models, and much more.

\section{E-learning Platform}

As it was mentioned above, e-learning platforms are usually made up on the basis of the university or any other virtual environment or cloud. The teachers of Russian Language Department of the Institute for Medicine at RUDN University use both the possibilities of the University and the private Moodle cloud.

Many courses are developed for the students that study Russian language at Medical Institute. For example, there is a course that is devoted to the participants that are going to study Russian language as foreign at the medical faculty. They may study it distantly to be able to come to Russia with B1 level (professional level) and to study at the Medical Faculty. The goal of the course is to form the communication skills at the level mentioned above. Selection, systematisation, methodical interpretation of language and speech material, which should be achieved by foreign students, are based on the principles of functional 
and communicative linguistics and communicative activity methods. The course includes different tools: lesson, URL, file, quiz, forum.
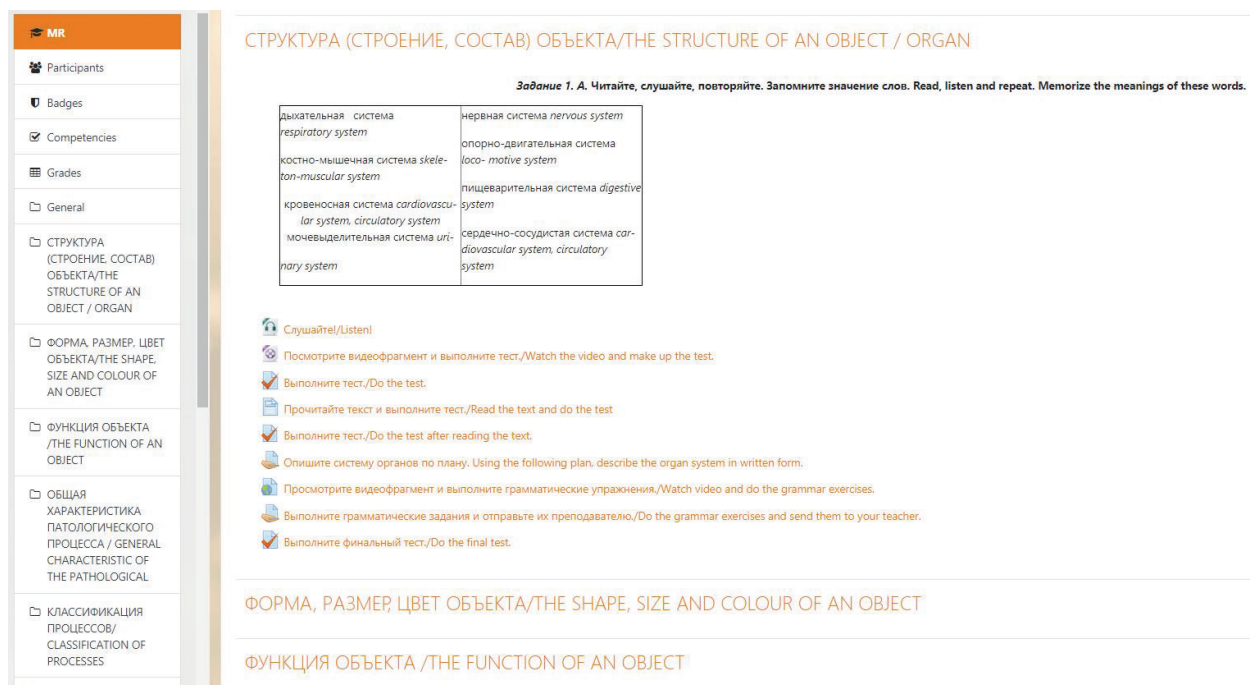

Figure 1. The example of e-learning platform "Medical Russian" in teaching Russian language as foreign for medical purposes.

The lesson activity gives the teacher an opportunity to introduce the material to the students in an interesting and flexible way. New terms and grammar rules are given with the help of this tool. Additional information may be inserted into the lesson activity with the help of the file activity that enables the teacher to provide a file as a course resource that is downloaded by the students. The students need to have the necessary software on the computers or smartphones to open the files.

The URL activity is also used as a course resource by the teacher. Any freely available online material can be linked, for example, video, documents, pictures, or websites.

After the introduction of the necessary material, its understanding may be checked with the help of the test that can be made up with the help of the quiz activity.

The quiz activity lets the teacher of Russian language as foreign create tasks for testing the material including multiple choice matching or short answers. This kind of tasks is often used by the teachers because tests are usually the most convenient way of checking any piece of knowledge: mini tests for reading to check the text comprehension, the grammar competence formation, and so on. The questions are usually shuffled or randomly selected from the question bank by the teacher, which limits the time as well. If the test's goal is training, the teacher can allow the quiz to be attempted several times. If it is the final knowledge check, the quiz is done only once. 
In this course the forum activity is incorporated. It enables the participants to have the asynchronous discussion. It may be used as a social place for the students to get acquainted, as a course announcement, as a space for discussion of a course content or reading materials, and as a one-on-one support area for private communication between a teacher and a student. Any student can start the discussion with any question he or she has. Files are allowed to be attached to posts. The participants subscribe to forum to get the information about new posts. These posts can be evaluated by teachers or students.

\section{E-mails}

E-mails are often used in the practice of online teaching Russian language as foreign for medical purposes. Usually, if one does not work with the students through e-learning platform, it is a good means of sending the teacher the compositions in the written form to be checked.

\section{Mobile Applications}

In teaching Russian language as foreign, mobile applications are becoming more and more popular among the students. At the moment, there are a lot of mobile applications that are made not only for the formation of grammatical skills, but also to check if they are formed or not. Moreover, not so long ago the mobile application TORFL GO for Android and IOS users was downloaded. It was created to prepare and check the proficiency level of Russian as a foreign language.

To check the level of proficiency in medical Russian as a foreign language, no mobile applications have been created so far. However, for the formation of skills of professional knowledge of the Russian language as a foreign language for medical purposes, teachers of Medical Institute of RUDN University actively use already created professional mobile applications that can be used by modern doctors in their professional activities. These applications contain a large number of terms and grammatical structures that can cause difficulties for future foreign doctors, whose activities are now impossible without them.

For example, modern doctors often use the special mobile application to see the consultations online, appointments, and so on. This application has its own structure and the way of operating with this mobile application. So, the teachers give special tasks to teach the students use this application.

\section{Methodology}

The pilot training course based on distance learning was conducted on the basis of the Peoples' Friendship University of Russia. 
The purpose was to verify the role of distance technologies and the distance learning in teaching the Russian language for medical purposes. 2 groups of postgraduate students from Arabic countries (Syria, Egypt, Libya) took part in the study. Initially, the postgraduates were offered either to study in a traditional way or to register and study the course online. Each group included 5 students. The starting level of language was homogeneous: B2 level of Russian as a foreign language proficiency. During the experiment, the students were suggested to take a test to check their knowledge, skills, and abilities. The test included five subtests: vocabulary and grammar, writing, listening, reading, and speaking. The materials for distant learning were presented as online tests for the participants. Speaking was examined online by Skype application.

\section{Results and Discussion}

As can be seen in Figure 2, Group 1 - studying online - showed the higher results in all aspects of language proficiency suggested in the sub-tests, whereas Group 2 - training in a traditional way of learning - showed the lower results.

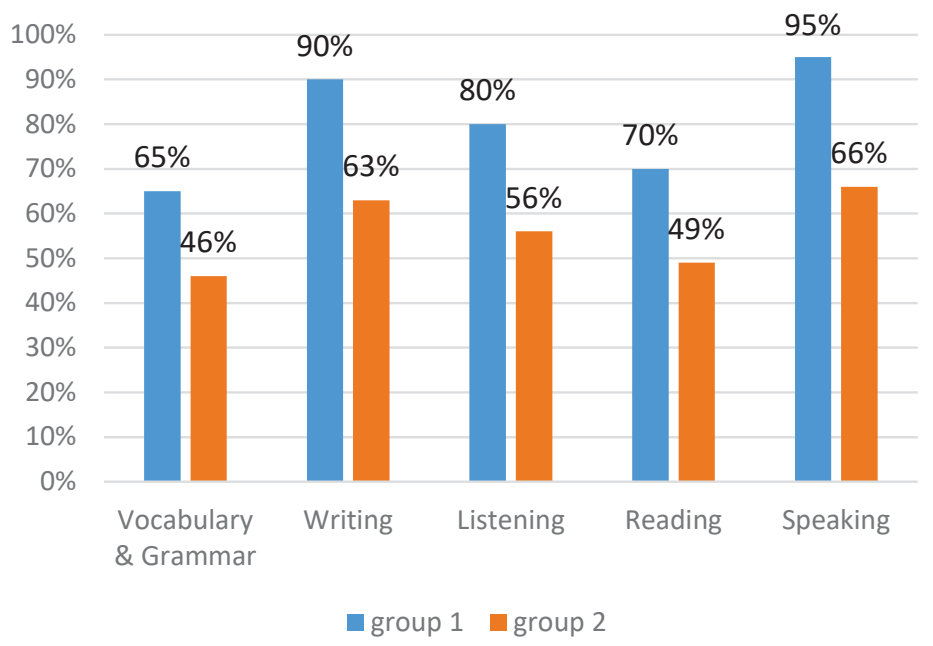

Figure 2. Examination results in the "Russian as a foreign language" module.

The scores of both groups are shown in Figure 2. Based on these data, the comparison of the results shows that the testees trained by means of distance learning have the results in all the sub-tests higher by $25-30 \%$ than those of language learners trained in a traditional way. In addition, not only quantitative but also qualitative changes should be noted in the language proficiency of the 
experimental group trainees: within the framework of the speaking sub-test, they began to use the language means more fluently and confidently, combine the adopted speech patterns, and choose the ways to express their thoughts. Thus, the experimental data showed the consistency of the proposed distance learning.

\section{Conclusions}

Distance language learning plays an important role in students' education. It is appropriate both for medical students that are going to begin studying at the university and for those who have finished their education but need to continue learning foreign languages for medical purposes. For this type of learning to be effective, while making up the distance course, the teachers have to use varied distance technologies that provide interactive online communication of students and teachers in the learning process and that give the learner the autonomy in the process of studying.

If we analyse the types of distance technologies that are provided by world methodological society, three basic classifications may be found: a set of distance technologies (desktop videoconferencing, e-mail, voicemail, online chat, webbased resources, e-learning platforms); synchronous/asynchronous technologies; m-learning/e-learning technologies.

In teaching foreign languages (Russian as a foreign language), the group of teachers of Russian Language Department of the Institute for Medicine (Peoples' Friendship University (RUDN University)) has developed several distant courses to arrange the education support for students that study Russian language as foreign for medical purposes at different levels. The authors suggest using the following distant technologies: synchronous technologies, professional websites, e-learning platforms, e-mails, mobile applications.

The verification of distant technologies' usage is conducted experimentally. The obtained results show that distance learning is useful and should be used in teaching Russian language as foreign for other levels and professional purposes.

In conclusion, it is necessary to add that the success of distance educational courses does not depend only on the distance technologies that are provided by a teacher; we should but also rely on the consistent and integrated efforts of students, faculty, facilitators, support staff, and administrators. 


\section{References}

Arafeh, S. (Ed.) (2004). The implications of information \& communications technologies for distance education: Looking toward the future (Final Report). Retrieved from http://www.sri.com/policy /csted/reports/sandt/it/Distance_Ed_Lit_Review_FINAL_6-9-04.pdf.

Brenton, S. (2009). E-learning - an introduction. A handbook for teaching and learning in higher education. Taylor\&Francis. Retrieved from: https://www.sun.ac.za/english/learning-teaching/ctl /Documents/A\%20Handbook\%20for\%20Teaching\%20and\%20Learning\%20in\%20Higher\% 20Education\%20Enhancing\%20academic\%20and\%20Practice.pdf (reference date: 06.02.2019).

Chongwony, L. K. E. (2008). An investigation of social presence in postsecondary learners enrolled in online learning environment. (Doctoral Dissertation). The College of Education of Ohio University. Retrieved from https://etd.ohiolink.edu/!etd.send_file?accession=ohioul199472454 \&disposition=inline (reference date: 01.02.2019).

Distance Education Models and Best Practices. (2011). Retrieved from https://www.imperial.edu/ ivc/files/Distance_Education_Models_and_Best_Practices.pdf (reference date: 06.02.2019).

Er, E., Özden, M., \& Arifoglu, A. (2009). A blended e-learning environment: A model proposition for integration of asynchronous and synchronous e-learning. International Journal Of Learning, 16(2), 449-460.

Harris, J., Mishra, P., \& Koehler, M. (2009). Teachers' technological pedagogical content knowledge and learning activity types: Curriculum-based technology integration reframed. Journal of Research on Technology in Education, 41(4), 393-416. Retrieved from http://learnonline .canberra.edu.au/file.php/5963/TPACK_UC/pdf/harris_mishra_koehler_jrte.pdf (reference date: 03.01.2019).

Hrastinski, S. (2008). Asynchronous \& synchronous e-learning. EDUCAUSE Quarterly, 31(4), 51-55. Retrieved from http://net.educause.edu/ir/library/pdf/eqm0848.pdf (reference date: 15.02.2019).

Kearney, M, Schuck, S., Burden, K., \& Aubusson, P. (2012) Viewing mobile learning from a pedagogical perspective. Research in learning technology, 20. Retrieved from https://journal .alt.ac.uk/index.php/rlt/article/view/1225/pdf (reference date: 25.01.2019).

Liu, Y. \& Ginther, D. (1999). Cognitive styles \& distance education. Online Journal of Distance Learning Administration, 2(3). Retrieved from http://www.westga.edu/ distance/liu23.html (reference date: 25.01.2019).

Motiwalla, L. F. (2007). Mobile learning: A framework and evaluation. Computers \& Education, 49(3), 581-596.

Prigozhina, K. \& Trostina, K. (2016). Modern distant and electronic technologies as triggers of enhanced professional language training opportunities in the system of higher education. Informatization of higher education: current situation and development prospects :materials of the II international scientific conference on October 12-13, 2016. Prague: Vědecko vydavatelské centrum «Sociosféra-CZ»

Sad, S. N. \& Goktas, O. (2013). Preservice teachers' perceptions about using mobile phones and laptops in education as mobile learning tools. British Journal of Educational Technology, 45(4), 606-618.

Schlosser, L. A., Ashland, O., \& Simonson, M. (Eds.). (2002) Distance education: Definition \& glossary of terms. Bloomington, IN: Association for Educational Communications \& Technology (AECT). Retrieved from http://www.nova.edu/ simsmich/pdf/jan\%2024.pdf (reference date: 30.01.2019).

Simonson, M., Smaldino, S., Albright, M., \& Zvacek, S. (2012). Teaching and learning at a distance: Foundations of distance education. (5th ed.). Boston: Pearson. 
Smyrnova-Trybulska, E. (2016). Some aspects of increasing the effectiveness and comfort of the scientific and educational process in university electronic environment. A research report. New Educational Review, 45(3), 259-270.

Towhidi, A. (2010). Distance education technologies and media utilization in higher education. International journal of instructional technology and distance learning, 7, 8, 3-30.

Unwin, D. \& Mc Aleese, R. (1988). The encyclopedia of educational media communications technology. New York: Greenwood Press.

Dmitry Guzhelya, Victoria Kurilenko, Yulia Biryukova

\title{
Nowe technologie w nauczaniu języków obcych dla potrzeb profesji medycznych
}

\author{
Streszczenie
}

Artykuł przedstawia analizę nowych technologii: zestaw technologii wykorzystywanych w nauczaniu na odległość (wideo-konferencje, e-mail, poczta wiadomości głosowych, rozmowy online, zasoby w sieci, platformy e-learningowe); technologie synchroniczne/asynchroniczne; technologie m-learningu/e-learningu. Te technologie zostały poddane badaniu naukowemu pod względem ich typologii, głównych cech charakterystycznych, potencjału językowego oraz metodologicznego.

Autorzy artykułu przedstawiają także technologie, które mogą być używane w nauczaniu języka rosyjskiego jako języka obcego dla profesji medycznych: omówiono technologie synchroniczne, profesjonalne strony internetowe, platformy e-learningowe, e-maile oraz aplikacje mobilne.

Wykorzystanie technologii do nauczania na odległość zweryfikowano eksperymentalnie. Uzyskane rezultaty pokazały, że nauczanie na odległość jest przydatne i powinno być wykorzystywane na różnych poziomach w nauczaniu języków obcych dla specjalistycznych celów zawodowych.

Powodzenie kursów prowadzonych metodą nauczania na odległość zależy nie tylko od technologii, których wykorzystanie umożliwia nauczyciel, lecz także powinno polegać na konsekwentnych wysiłkach studentów, wydziałów, koordynatorów, obsługi technicznej oraz administracyjnej.

S łow a kluc z ow e: nauczanie na odległość, nauczanie języków obcych dla potrzeb zawodowych, technologie nauczania na odległość, język rosyjski w profesjach medycznych

Dmitry Guzhelya, Victoria Kurilenko, Yulia Biryukova

\section{Дистанционные технологии в обучении иностранному языку в профессиональных (медицинских) целях}

Анн н т а ция

В статье представлен анализ дистанционных технологий, представленных мировым методологическим сообществом: совокупность дистанционных технологий (настольные видеоконференции, электронная почта, голосовая почта, онлайн-чат, веб-ресурсы, платформы электронного обучения); синхронные/асинхронные технологии, технологии мобильного дистанционного обучения/ дистанционного обучения. Эти технологии были проанализированы 
с научных позиций с точки зрения типологии, сущностных характеристик, лингвистического и методологического потенциала.

Авторы статьи также приводят дистанционные технологии, которые могут быть использованы при обучении русскому языку как иностранному в медицинских целях: синхронные технологии, профессиональные сайты, платформы электронного обучения, электронная почта, мобильные приложения.

Экспериментально проведена проверка использования дистанционных технологий. Полученные результаты показывают, что дистанционное обучение полезно и должно использоваться в обучении иностранным языкам для других уровней и профессиональных целей.

Успех дистанционных образовательных курсов зависит не только от дистанционных технологий, предоставленных преподавателем, но и от последовательных и комплексных усилий студентов, преподавателей, вспомогательного персонала, администраторов.

К л ю ч е в ы е с л о в а: дистанционное обучение, обучение языку профессии, дистанционные технологии, медицинский русский

Dmitry Guzhelya, Victoria Kurilenko, Yulia Biryukova

\section{Tecnologías a distancia en la enseñanza de lenguas extranjeras profesionales con fines médicos}

\section{Resumen}

El artículo presenta el análisis de tecnologías distantes descubiertas por la sociedad metodológica mundial: un conjunto de tecnologías a distancia (videoconferencia de escritorio, correo electrónico, correo de voz, chat en línea, recursos basados en la web, plataformas de aprendizaje electrónico); tecnologías síncronas / asíncronas, tecnologías m-learning / e-learning. Estas tecnologías fueron analizadas desde posiciones científicas en cuanto a su tipología, características esenciales, potencial lingüístico y metodológico.

Los autores del artículo también proporcionan tecnologías a distancia que se pueden utilizar cuando se enseña el idioma ruso como extranjero con fines médicos: tecnologías sincrónicas, sitios web profesionales, plataformas de aprendizaje electrónico, correos electrónicos, aplicaciones móviles.

La verificación del uso de tecnologías distantes se realiza experimentalmente. Los resultados obtenidos muestran que el aprendizaje a distancia es útil y debe usarse en la enseñanza de idiomas extranjeros para otros niveles y propósitos profesionales.

El éxito de los cursos educativos a distancia depende no solo de las tecnologías a distancia que proporciona un maestro, sino que también debemos confiar en los esfuerzos consistentes e integrados de los estudiantes, profesores, facilitadores, personal de apoyo y administradores.

P a labras clave: aprendizaje a distancia, enseñanza de lenguas extranjeras profesionales, tecnologías a distancia, ruso médico 